\title{
Equipment Leasing Model with Failure Tolerance Cost Using Game Theory
}

\author{
Bayu Nur Abdallah ${ }^{1}$, Ahmad Jamil ${ }^{1}$, and Nani Kurniati ${ }^{2}$ \\ ${ }^{1}$ Department of Industrial Engineering, Institut Teknologi Kalimantan, Indonesia \\ ${ }^{2}$ Department of Industrial Engineering, Institut Teknologi Sepuluh Nopember, Indonesia \\ e-mail: bayunur@lecturer.itk.ac.id
}

\begin{abstract}
In this study the equipment lease contract, where two players, the lessor, lease the equipment to the user (lessee), if the equipment fails to exceed the tolerance agreed by both players during the lease period and needs to be repaired, it is considered detrimental to the lessee, because it results in a loss of potential revenue will be received from leased equipment. Therefore, the total income of the lessor in the lease contract may incur penalty costs as a consequence of the lessor for failure to maintain maintenance performance. We use Nash's game theory formulation to find a win-win solution between players where it is an equilibrium point for lessor and lessee. The results of this study are, when Lessee decides to maximize profits, which is the total potential profit gained by the lessee using leased equipment, and the lessor also decides to maximize their profits derived from the leased equipment by considering penalty cost as a cooperatively determined variable. The selected scenario is the percentage of the minimum penalty cost with the maximum level of equipment used.
\end{abstract}

Keywords-Lease Equipment, Maintenance, Penalty Cost, Exceed Failure, Game Theory.

\section{INTRODUCTION}

$\mathrm{L}$ EASING, according to [1], is a contract in which a user (lessee) uses the equipment of another person, in this case the owner (lessor), with the terms of the lessee and a cost for the lessor. To prevent the leased equipment from declining performance, an equipment is unreliable, maintenance services are indispensable. According to [2], such actions may include preventive maintenance (PM) and Corrective Maintenance (CM). PM measures are used to control the performance degradation of an apparatus that may cause an equipment failure to operate. CM action is used to return equipment that has decreased performance to reoperate to a certain operational status. In determining the optimal preventive maintenance strategy, that takes into account all costs to minimize the total cost expected to the lessor for leasing new equipment.

Based on several cases that occur in leasing equipment company, maintenance treatment to leased equipment is done during the rental period and when the equipment is damaged. Therefore, the maintenance that occurs in the leasing equipment company during the lease period is often in the form of equipment repair (CM), not just the preventive maintenance (PM) which is performed periodically. This creates during the repair period, the equipment can not be used by the lessee causing the potential loss of revenue. This event will not occur if the equipment does not damage during the lease period.
If equipment repairs in the middle of the lease period are inevitable, the imposition of penalty cost, as a consequence for the lessor, is inevitable. This may occur because of a nonoptimal CM strategy, that is, due to delays in performing CM and because of frequent CM frequencies. [2]. The imposition of this penalty cost charge is crucial. Besides it is necessary to determine the optimal percentage, it is necessary to consider both parties, lessee and lessor, in decision making. CM optimization needs to be done in this case both sides determine the equilibrium scenario, win-win solution, for both parties. Therefore, it is necessary to make a maintenance scenario by considering it. This research uses heavy equipment leasing object due to high failure characteristic in heavy equipment. The high frequency of failure causes CM treatment in the middle of the lease period.

This causes the equipment to stop operating and can not be used so that lessees lose in terms of potential revenue loss. There is a need for the lessor to provide several maintenance measures to avoid repairs and penalties caused by the failure of the product [3]. For the equipment failure, the model boundary by point process with function of intensity that depend on that usage and age of equipment [4]

We choose game theory as a scenario selection method because game theory is known as an effective tool for solving system problems that use interactions between decision makers. Decisions made by the players must be rational. In other words, game theory approaches are an effective way to analyze the strategic behavior of rational decision makers. [5]. The study of lease equipment with game theory approach by [6] are set a comparison of total profits to establish conditions under which non-cooperative rents perform poorly and thus lessees and lessors can earn significantly more profits by switching to cooperatives. It should be emphasized that the application of cooperative solutions is a win-win solution and provides flexibility in allocating additional benefits through coordination. In this case the cooperative game-theory solution requires the main criteria, that is, cooperation must lead to a win-win solution situation for the lessee and the lessor [7].

This study addresses the circumstances that occur when the equipment leased by the lessee suffers damage beyond the maintenance period so that the equipment requires corrective maintenance to restore the condition of the equipment to be ready for reuse. To overcome the losses suffered by the lessee in the form of loss of potential revenue due to the leased equipment can not be used, the lessor is obligated to pay penalty cost for any corrective maintenance occurring. This paper aims to build a mathematical model of a lease 
The $1^{\text {st }}$ International Conference on Business and Engineering Management (IConBEM)

February $1^{\text {st }} 2020$, Institut Teknologi Sepuluh Nopember, Surabaya, Indonesia

Table 1

Payoff Lessee and Lessor based Penalty Cost 20\% of Labor Cost (all units of currency is Rupiah)

\begin{tabular}{ccccccccc}
\hline \hline Max Rev & Usage & Lease Period & Life Cycle & Penalti Cost & Number of PM & Payoff Lessee & Payoff Lessor & Total Revenue \\
\hline $36,000,000$ & 12,000 & 10 & 10 & 44,000 & 9 & $208,892,000$ & $137,916,000$ & $346,808,000$ \\
$40,000,000$ & 14,000 & 10 & 10 & 44,000 & 10 & $260,354,000$ & $162,206,000$ & $422,560,000$ \\
$44,000,000$ & 16,000 & 10 & 10 & 44,000 & 11 & $317,543,000$ & $189,476,000$ & $507,019,000$ \\
$48,000,000$ & 18,000 & 10 & 10 & 44,000 & 11 & $377,892,000$ & $203,616,000$ & $581,508,000$ \\
$60,000,000$ & 20,000 & 10 & 10 & 44,000 & 13 & $578,587,000$ & $306,626,000$ & $885,213,000$ \\
\hline \hline
\end{tabular}

Table 2

Payoff Lessee and Lessor based Penalty Cost $40 \%$ of Labor Cost (all units of currency is Rupiah)

\begin{tabular}{ccccccccc}
\hline \hline Max Rev & Usage & Lease Period & Life Cycle & Penalti Cost & Number of PM & Payoff Lessee & Payoff Lessor & Total Revenue \\
\hline $36,000,000$ & 12,000 & 10 & 10 & 88,000 & 9 & $208,936,000$ & $137,872,000$ & $346,808,000$ \\
$40,000,000$ & 14,000 & 10 & 10 & 88,000 & 10 & $260,398,000$ & $162,162,000$ & $422,560,000$ \\
$44,000,000$ & 16,000 & 10 & 10 & 88,000 & 11 & $317,587,000$ & $189,432,000$ & $507,019,000$ \\
$48,000,000$ & 18,000 & 10 & 10 & 88,000 & 11 & $377,936,000$ & $203,572,000$ & $581,508,000$ \\
$60,000,000$ & 20,000 & 10 & 10 & 88,000 & 13 & $578,631,000$ & $306,582,000$ & $885,213,000$ \\
\hline \hline
\end{tabular}

equipment model based on penalty cost on each corrective maintenance. So it can know the equilibrium maintenance scenario for the lessor and lessee in the lease equipment by considering penalties imposed on the lessor based on cooperative game theory. This paper is organized as follows. The mathematical formulations for equipment failure intensity, maintenance costs, revenue, residual value, in the section 2, as well as the lessee's and the lessor's payoff functions. Section 3 presents numerical examples to illustrate the cooperative scheme based penalty cost and to investigate their performance on result and discussion by the paper

\section{MATHEMATICAL MODEL / METHOD}

\section{A. Payoff lessee}

On the lessee, the function of the objective to be achieved is maximization of total potential profit obtained by the lessee by using equipment that is leased with the following formulation:

$\operatorname{Max} \Pi_{1}(K)=\frac{u_{m}}{r_{m}} \frac{r K}{L}\left[L-\frac{K(1+\delta N)}{2(N+1)}\right]-\alpha_{0} r^{2} K+\sum_{n=1} C n$

Specifically, the total profit of the lessee is $\Pi_{1}(K)$ that means that the total profit the lessee on the first payoff is determined by the length of the rental period $(\mathrm{K})$. It is affected that the payoff based on usage rate, lease period, number of PM, the degree of each PM. Payoff is calculated taking into account the revenue generated by the equipment and the total price paid for the rent also sum of penalty cost paid to lesson. Payoff lessor

On the lessor, to achieve the objective function is the maksimasi profit obtained through charges that the lessee pay to rent the equipment minus with cost of PM, cost of depreciation expenses, and equipment with the following formulation:

$Y(r, K, N, \delta)-C p-(C m+C n)-S v$

$\operatorname{Max} \Pi_{2}(N, \delta)=\alpha_{0} r^{2} K-\left[N a+\frac{N b K(1-\delta)}{N+1}\right]-\left[\left(C_{f}+\right.\right.$ $\left.\left.C_{n}\right) K^{2}\left(\theta_{1} r+\theta_{2}\right) \frac{(N \delta+1)}{2(N+1)}\right]-\left[K^{2}\left(\theta_{3} r^{2}+\theta_{4}\right) \frac{(N \delta+1)^{2}}{(N+1)^{2}}\right]$

Payoff the lessor is determined by the large amount of treatment PM $(\mathrm{N})$ and the magnitude of the degree of maintenance during the period of lease $(\delta)$. This second payoff influenced based on usage rate, lease period, number of PM, PM of each degree and the penalty cost.
The following is list of notations which are used in the model. $Y(r, K, N, \delta)=$ Total revenue based usage rate, lease period, number of PM, degree of each $P M$

$C p=$ Total cost of $P M$

$\mathrm{Cm}=$ Total cost of $\mathrm{CM}$

$S v=$ residual value

$u_{m}=$ potential revenue

$r_{m}=$ Maximum usage rate

$r \quad=$ Usage rate

$K=$ Lease Period

$L \quad=$ Life cycle equipment

$\delta=$ degree maintenance of each PM

$N=$ Number of PM

$a \quad=$ Fixed cost of each PM

$b=$ Variable cost of each PM

$C_{f}=$ Cost of each CM

$\theta_{1}=$ koefisien usage 1

$\theta_{2}=$ koefisien usage 2

$\theta_{3}=$ koefisien usage 3

$\theta_{4}=$ koefisien usage 4

$\Phi_{2}=$ Total penalty cost tipe-2

$C_{n}=$ penalty cost of each $C M N(t)>0$ (penalti type 2)

$n=$ number of failure

\section{FINDINGS / RESULT AND DISCUSSION}

In this study we used a case study of a heavy equipment leasing, Company $\mathrm{X}$. when this company rents heavy equipment to company $\mathrm{Y}$, a damage occurs during the lease period. Based on leasing contract, the company $\mathrm{X}$ should be penalized by paying a penalty cost which calculate by labor cost of maintenance. The createria of lease contract are below.

The initial value of the vehicle is $s V_{0}=\mathrm{Rp} .200 .000 .000$. Its life cycle is $\mathrm{L}=10$ years, and the maximum usage rate of the vehicle is $r_{m}=20.000 \mathrm{~km} /$ year. If the lessee leases the vehicle for one year at the maximum usage rate $r_{m}=20.000 \mathrm{~km} /$ year, he needs to pay the lessor Rp. 28.000.000 $\alpha_{0}$ ). The vehicle generates up to Rp. 60.000 .000 annual revenue $\mathrm{u}$ m $=\mathrm{Rp}$. $60.000 .000 /$ year) for the lessee, and the salvage value of the vehicle is Rp. 20.000.000 after 10 years of usage at the highest annual usage rate $\left(r_{m}\right)$. Labor cost of each CM is Rp. 220.000. Estimated corrective maintenance happen 1 in every single lease period. 

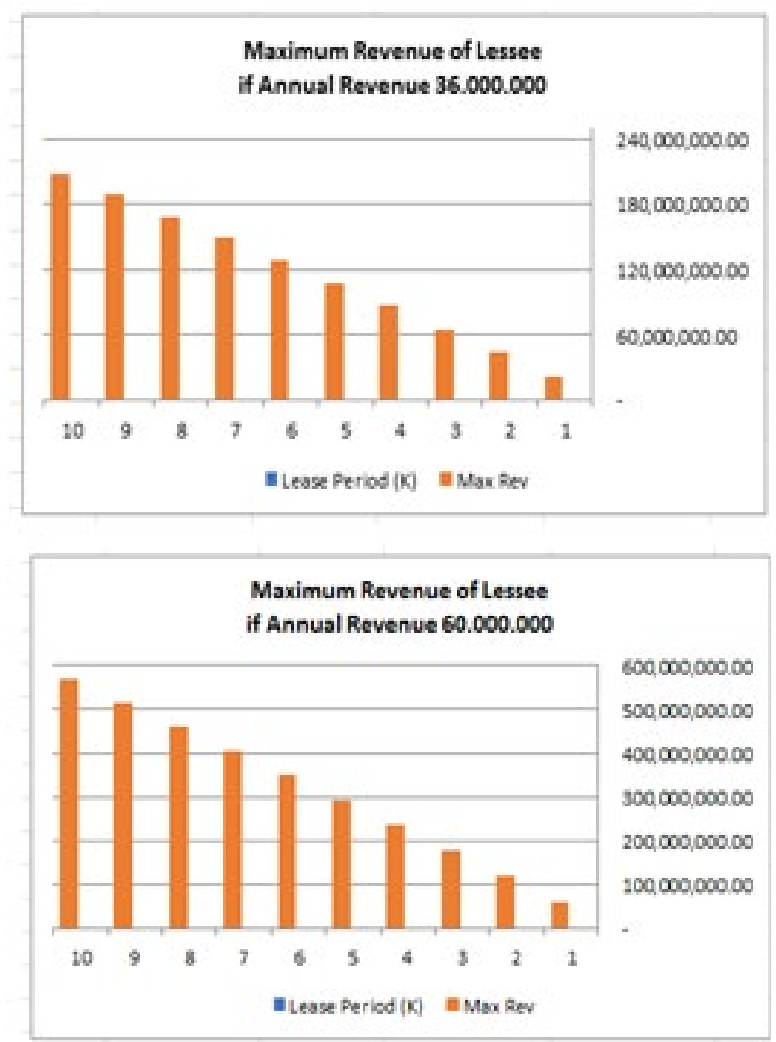

Figure 1. Relative increase in maximum revenue during 1-10 lease period.

Figure 1 is the summary result based on numerical experiment of leased period. Both are compared, annual revenue of 36.000 .000 and 60.000 .000 . After numerical experiments by changing the lease period from 1 to 10 years, the highest maximum revenue occurs when the lease period for 10 years.

Table 1 is the summary result payoff lessee and lessor after giving penalty cost from $20 \%$ labor cost of CM compared by result payoff lessee and lessor after giving penalty cost from $40 \%$ labor cost of CM in Table 2. After the addition of variable penalty cost of $20 \%$ of labor costs when performing the $\mathrm{CM}$, generated the maximum profit received by the lessee and lessor occurs when the usage rate is 20,000 and the number of PM as 13 is $578,587,000$ and $306,626,000$. If penalty cost of $40 \%$ of labor costs when performing the CM, the maximum profit received by the lessee and lessor occurs when the usage rate is 20,000 and the number of PM as 13 is increase to $578,631,000$ and profit lessor decrease to $306,582,000$.

\section{CONCLUSSION}

This research produce mathematical model and the design of decision making tools for the determination of penalty cost that can be added to lessee and lessor payoff formula. It can be concluded that the maximum profit that can be received by the lessee and lessor while the usage rate and lease period are optimum. Optimal maintenance scenarios taking into account the existence of a usage rate and penalty charged to the lessor based on cooperative game theory.

The percentage component of the penalty cost is proven to be different if the lessee's and lessor's profit are separated, the lessee wants a large percentage of penalty cost while the lessor wants a small percentage of penalty cost. But is shown to have no impact on the total revenue received by the lessee and lessor if accumulated using cooperative. a combination of scenario S S 1.5 and 2.1. Equilibrium is obtained when the player 1 st.

\section{ACKNOWLEDGEMENT}

This work is supported by the LPPM ITK research grant 2019.

\section{REFERENCES}

[1] L. Deelen, M. Dupleich, and L. Othieno, Leasing for Small and Micro Enterprises : a Guide for Designing and Managing Leasing Schemes in Developing Countries. Geneva : International Labour Office, 2003.

[2] J. Jaturonnatee, D. N. P. Murthy, and R. Boondiskulchok, "Optimal preventive maintenance of leased equipment with corrective minimal repairs," Eur. J. Oper. Res., vol. 174, no. 1, pp. 201-215, Oct. 2006, doi: 10.1016/J.EJOR.2005.01.049.

[3] R. H. Yeh, K.-C. Kao, and W. Liang Chang, "Preventive-maintenance policy for leased products under various maintenance costs," Expert Syst. with Appl., vol. 38, pp. 3558-3562, 2011, doi: 10.1016/j.eswa.2010.08.144.

[4] B. P. Iskandar, D. N. P. Murthy, and N. Jack, "A new repair-replace strategy for items sold with a two-dimensional warranty," Comput. Oper. Res., vol. 32, no. 3, pp. 669-682, 2005, doi: 10.1016/j.cor.2003.08.011.

[5] S. Abapour, M. Nazari-Heris, • Behnam Mohammadi-Ivatloo, • Mehrdad, and T. Hagh, "Game Theory Approaches for the Solution of Power System Problems: A Comprehensive Review," Arch. Comput. Methods Eng., vol. 27, pp. 81-103, 2020, doi: 10.1007/s11831-0189299-7.

[6] M. Hamidi, H. Liao, and F. Szidarovszky, "Non-cooperative and cooperative game-theoretic models for usage-based lease contracts," Eur. J. Oper. Res., vol. 255, pp. 163-174, 2016, doi: 10.1016/j.ejor.2016.04.064.

[7] H. Tarakci, K. Tang, H. Moskowitz, and R. Plante, "Incentive maintenance outsourcing contracts for channel coordination and improvement," IIE Trans. (Institute Ind. Eng., vol. 38, no. 8, pp. 671684, 2006, doi: 10.1080/07408170600692259. 